\title{
Individual differences in adolescent religiosity in Finland: familial effects are modified by sex and region of residence
}

\author{
Torsten Winter ${ }^{1}$, Jaakko Kaprio ${ }^{1,2}$, Richard JViken ${ }^{3}$, Sakari Karvonen ${ }^{1}$ and Richard J Rose ${ }^{3}$ \\ ${ }^{1}$ Department of Public Health, University of Helsinki \\ ${ }^{2}$ Department of Mental Health and Alcohol Research, National Public Health Institute, Helsinki, Finland \\ ${ }^{3}$ Department of Psychology, Indiana University, Bloomington, Indiana, USA
}

\begin{abstract}
Data from 16-year-old Finnish twin pairs were used to estimate familial effects on religiosity and the modification of those effects by sex and residential region. The sample of 2265 twin boys and 2521 twin girls formed 779 monozygotic and 1614 dizygotic pairs, 785 of the same sex and 829 of opposite sex. We compared religiosity scores of twins living in more rural and traditional northern Finland with those living in the more urban and secular southern region. Girls had higher religiosity scores than did boys, and twins living in northern Finland had higher religiosity scores than those resident in southern Finland. Correlations for monozygotic twins were slightly higher than those for dizygotic twins, and covariance modeling found modest heritability of religiosity [11\% $(95 \% \mathrm{Cl} 0-24)$ for girls; $22 \%(95 \% \mathrm{Cl} 6-38)$ for boys], and substantial shared environmental effects $[60 \%(95 \% \mathrm{Cl} 49-69)$ and $45 \%(95 \% \mathrm{Cl} 31-57)]$ among girls and boys, respectively. The correlation between shared environmental effects in boys and girls was estimated to be $0.84(95 \%$ $\mathrm{Cl}$ 0.73-0.99). In analyses distinguishing region of residence, girls living in southern Finland were found to have significantly higher unshared environmental effects than girls in northern Finland, while boys living in the urban south appeared to have lower shared environmental effects, and higher additive genetic effects, than boys living in the rural north.
\end{abstract}

Keywords: Wiggins, religiosity, MMPI, genetic factors, adolescence, area of residence

\section{Introduction}

Finnish studies of adolescent alcohol use show regional variation that reflects social norms and religious cultures, as well as socio-economic differences. ${ }^{1}$ There is regional variation also in the relationship of parents' alcohol use to the health behavior of their adolescent children. Parents' drinking habits in the more densely populated southern Finland appear to exert less influence on rates of abstinence of adolescent offspring than in the north of the country. ${ }^{2}$ Other comparisons of youth behavior between Ostrobothnia, in northern Finland, and Uusimaa, in southern Finland, ${ }^{3-5}$ further highlight the relevance of investigating regional and religious differences.

Religiosity has been conceptualized as a cognitive/ personality attribute that, in adolescence, functions to control deviant behavior; ${ }^{6}$ that control may be mediated in different, convergent ways: (i) participation in religious rituals places the adolescent in conventional social activities and a sanctioning

Correspondence: Richard J Rose, Department of Psychology, Indiana University, 1101 E10th Street, Bloomington, Indiana 47405-1301, USA. Fax: 812855 4691; E-mail: Rose@ndiana.edu Received 19 April 1999; accepted 20 April 1999 network; (ii) religious teaching can foster awareness of moral standards; (iii) religious ideology may foster personal control via anticipated punishment for transgression; and (iv) emotional religious experience may generate a devout, reverent, obedient adjustment. There is substantial evidence that religiosity does buffer adolescents (and adults) against substance abuse and health-compromising behavior, ${ }^{7,8}$ and some evidence suggests that the buffering effect is largely indirect, through peer-selection processes $^{9,10}$ that promote affiliation among conforming, non-deviant, religious adol escents. In Finland, too, adults and adolescents who regard themselves as religious, and those who attend church, drink less than others. ${ }^{11}$

Finland is a quite homogeneous country in relation to religious matters. The Protestant church has played an important role in shaping the nation and its culture and today $86 \%$ of the population are members of the Evangelical Lutheran Church. Only $1 \%$ bel ongs to the Orthodox church, and $1 \%$ to other religious communities, $12 \%$ are not church members, but only $16 \%$ of these regard themselves as atheists. ${ }^{12}$ For the last two decades, religion in Nordic countries has been an individual matter, not something people do together. Compared with other countries, Finns very seldom go to church (1.8 times/ 
year), and Finland can, in this respect, be seen as a secularised society. ${ }^{12}$ How ever, according to opinion polls, Finns regard the church as an important institution, and, for example, $97 \%$ of Finns have a church funeral. ${ }^{13}$ Importantly, nearly all adolescents at age 15 attend confirmation classes ( $91 \%$ of church members, and $41 \%$ of non-members), evidence of its importance in the lives of Finnish adolescents.

Most of those who do not belong to the Church, do not believe in God, and seldom pray, live in the greater Helsinki capital area and the old industrial capital of Tampere, both in the southern area of Finland. ${ }^{13}$ Most of the religious movements operate within the church; they are often rather fundamental (revivalist), and find their supporters mostly in the northern, rural parts of the country. ${ }^{14}$ One of oldest and most widespread of these is the Laestadian movement, which became active at least in part to promote abstinence. ${ }^{15}$ Prohibition of alcohol use remains a central tenet of the Laestadian movement.

Twin and family studies document transmission of both genetic and familial-environmental influences on adolescent alcohol use, and, because familial influences may be mediated by religious beliefs and practices, we have assessed contributions of genetic and shared environmental effects on religiosity in a population-based sample of adolescent twins in Finland. And, because the southern and northern regions of Finland differ in the extent of religious beliefs and use of alcohol, we have asked whether the relative role of genetic and environmental effects on religiosity vary between the two regions of Finland.

\section{Materials and methods}

\section{Subjects}

Finnish twins from five consecutive and complete birth cohorts, born in 1975-1979, form a study (FinnTwin16), in which baseline assessments were sequentially made, during 1991-1995, within two months of the twins' 16th birthdays. ${ }^{2}$ The baseline questionnaire assessment included items on health, health behavior and attitudes, as well as 163 items, forming six scal es from the MMPI. The full five-year cohort of twins born in 1975-1979 yielded replies from 5563 twin individuals (response rates were $88 \%$ for boys and $93 \%$ for girls). The average age of respondent twins was 16.2 years. In $81 \%$ of the families, both parents lived together with the twins.

We excluded individual twins from our analysis for one or more of the following reasons: (i) only one twin in a pair returned the baseline questionnaire ( $n$ = 93); (ii) zygosity could not be determined from questionnaire responses $(n=202)$; (iii) twins resided on the Åland islands $(n=21)$ or were resident abroad ( $n=9$ ); (iv) twins could not answer the questionnaire themselves due to illness/disability $(n=11)$; $(v)$ respondent twins omitted up to three of the 12 REL scale items $(n=273)$ or only one twin in the pair had a REL score $(n=191)$. A total of 777 twins were excluded, as there was some overlap in exclusion criteria. The remaining 4786 twins ( 2265 boys and $2521 \mathrm{girls}$ ) were included in our anal yses.

Zygosity was determined by questionnaire responses, as described in detail elsewhere. ${ }^{16}$ Supplemental information on zygosity was obtained from photographs and DNA fingerprinting in some cases. The 2393 twins pairs were classified into female and male monozygotic (MZ) pairs ( $F M Z=460$ pairs, $M M Z=319$ pairs) and two groups of dizygotic (DZ) pairs; same-sex dizygotic (SSDZ, FDZ = 386 pairs, MDZ = 399 pairs) and opposite-sex dizygotic (OSDZ, 829 pairs).

\section{Measures: the REL scale}

Religiosity was measured with the (REL)ligious Fundamentalism scale, ${ }^{17}$ one of 13 scales identified by content analysis of the item pool of the MMPI, the Minnesota Multiphasic Personality Inventory. The REL scale consists of 12 declarative statements (listed in Table1) that respondents are asked to endorse as true or false. The 12 items were distributed, as ordered in the full MMPI, within $163 \mathrm{MMPI}$ items included in the baseline questionnaire. The internal consistency of the REL scale, assessed by Cronbach's alpha, is satisfactory: 0.82 for girls, and 0.81 for boys; test-retest reliability of 0.95 for males and 0.93 for females has been reported. ${ }^{17}$

\section{Differentiation of Finland into northern and southern regions}

To study regional effects on REL scale scores and on their genetic and environmental influences, we used the Nomenclature des Unités Territoriales Statistiques, a regional classification system of the European Union. ${ }^{18}$ We divided the country into two areas, one consists of Uusimaa, the area surrounding Helsinki, together with other southern regions (here called southern Finland), the other consisting of all remaining central, eastern, and northern areas of Finland (here called northern Finland). The population of southern Finland, so defined, is 3.14 million, yielding a density of $45 \mathrm{inhabitants} / \mathrm{km}^{2}$, contrasted with a population density of seven inhabitants $/ \mathrm{km}^{2}$ for the 1.97 million Finns resident in what we are calling northern Finland. ${ }^{19}$ There were two pairs discordant for residence, one twin residing in the 
Table 1 Percentage answering 'true' to the 12 items Wiggins Religious Fundamentalism (REL) scale; 16-year-old adolescents in the north and south of Finland $(\mathrm{N}=4786)$

\begin{tabular}{|c|c|c|c|c|c|c|}
\hline & \multicolumn{2}{|c|}{ South } & \multicolumn{2}{|c|}{ North } & \multicolumn{2}{|c|}{$\chi^{2} \mathrm{P}$-value } \\
\hline & boys & girls & boys & girls & boys & girls \\
\hline \multicolumn{7}{|l|}{ 1. Everything is turning out just like the prophets of the } \\
\hline Bible said it would & 14 & 16 & 20 & 28 & 0.001 & 0.001 \\
\hline 2. I go to church almost every week & 2 & 3 & 3 & 5 & 0.554 & 0.026 \\
\hline 3. I believe in the second coming of Christ & 22 & 25 & 31 & 38 & 0.001 & 0.001 \\
\hline 4. I believe in a life hereafter & 50 & 63 & 52 & 66 & 0.619 & 0.108 \\
\hline 5. I am very religious (more than most people) & 13 & 16 & 18 & 19 & 0.002 & 0.044 \\
\hline 6. I believe there is a Devil and Hell in the afterlife & 25 & 27 & 30 & 39 & 0.011 & 0.001 \\
\hline 7. I believe there is a God & 59 & 73 & 63 & 80 & 0.125 & 0.001 \\
\hline 8. I feel sure that there is only one true religion & 29 & 24 & 36 & 31 & 0.001 & 0.001 \\
\hline 9. Christ performed miracles such as changing water into wine & 52 & 62 & 59 & 73 & 0.002 & 0.001 \\
\hline 10. I pray several times a week & 17 & 32 & 20 & 42 & 0.129 & 0.001 \\
\hline 11. I read the Bible several times a week & 2 & 4 & 3 & 6 & 0.086 & 0.042 \\
\hline $\begin{array}{l}\text { 12. I have no patience with people who believe there is only one } \\
\text { true religion }\end{array}$ & 25 & 29 & 25 & 29 & 0.924 & 0.970 \\
\hline
\end{tabular}

Southern region, the other in the Northern region. These pairs were randomly assigned to the regions, one to the Southern region, the other pair to the Northern region. The Swedish-speaking population makes up about $6 \%$ of the population. The data includes both Finnish and Swedish-speaking adolescent twins; response rates were al most the same for both language groups. The few pairs living in the Åland island archipelago were excluded, because of the islands' special historical position within Finland.

\section{Statistical analyses}

Statistical analyses were performed by standard methods in SAS, TWINAN ${ }^{20}$ and Mx. ${ }^{21}$ TWINAN was used to test for homogeneity of means and variances across twin type. We fitted standard sexlimitation model $\mathrm{s}^{22}$ to the twin covariance matrices for the five zygosity groups. These models allow estimation of the genetic and environmental effects influencing REL scores, tests of differences in the magnitude of genetic and environmental effects for girls and boys, and a test of the hypothesis that different shared environmental or genetic effects may be influencing REL in girls and boys. After estimating this model for the complete sample, we fitted a ten-group model that distinguished twins living in the north and the south. This model allowed additional tests of differences in genetic and environmental influences on REL in different regions of the country.

\section{Results}

Endorsement frequencies for the 12REL scale items by region and sex are shown in Table1. For 10 of the items, girls living in Northern Finland have the highest endorsement percentages, and in these items, boys living in Southern Finland have the lowest endorsement percentages. Among the girls, those resident in the northern region have significantly higher scores for 10 items than do girls from the southern region. For half of the items, boys from the north have significantly higher endorsement rates; there are no items that boys from the south endorse more than do boys from the north, and the same is true among the girls. Responses to the item 'I feel sure that there is only one true religion' are an exception, in that endorsement rates are higher among boys in both the south and the north than among girls. At the same time boys show less tolerance against those who believe there is only one true religion.

Mean REL scores were higher for girls than for boys in the full sample, and in all zygosity and residential areas groups (Table2). Scale means and

Table 2 Means and standard deviations for the Wiggin's REL scale among adolescent Finnish twins (FinnTwin 16 study) by zygosity (the whole country) and by sex (the whole country), North; South $(n=4786)$

\begin{tabular}{llrrr}
\hline Area & & No. subjects & Mean & $\begin{array}{c}\text { Standard } \\
\text { deviation }\end{array}$ \\
\hline \multirow{2}{*}{ All } & MZ girls & 920 & 4.47 & 2.90 \\
& MZ boys & 638 & 3.78 & 2.79 \\
& SS DZ girls & 772 & 4.71 & 3.02 \\
& SS DZ boys & 798 & 3.90 & 2.70 \\
& OS DZ girls & 829 & 4.35 & 2.85 \\
& OS DZ boys & 829 & 3.75 & 2.79 \\
Full sample & Girls & 2521 & 4.50 & 2.92 \\
& Boys & 2265 & 3.81 & 2.76 \\
Southern region & Girls & 1409 & 4.15 & 2.79 \\
& Boys & 1283 & 3.61 & 2.66 \\
Northern region & Girls & 1112 & 4.96 & 3.01 \\
& Boys & 982 & 4.08 & 2.86 \\
\hline
\end{tabular}

SS = same sex pairs, OS = opposite sex pairs 
variances did not differ by zygosity within sexes. Twins living in northern Finland had higher scores than those in southern Finland for both sexes.

The REL correlations were slightly higher for $M Z$ pairs than for DZ pairs (Table 3). The correlations for SS DZ pairs were higher than for OS DZ pairs in the nationwide sample. In southern Finland, the correlations among girls did not differ for MZ and SS DZ pairs, whilst male $M Z$ pairs had a higher correlation than SS DZ pairs. In northern Finland the MZ/DZ differences were very small for both girls and boys.

A general sex-limitation model estimating additive genetic (A), shared environmental (C), and unshared environmental (E) effects on REL, and allowing different shared environmental effects for boys and girls, provided an excellent fit to the data $\left(\chi^{2}=5.411, \mathrm{df}=8, \mathrm{P}=0.713\right)$. Parameter estimates (standardized to reflect percentage of phenotypic variance accounted for) and $95 \%$ confidence intervals for the estimates are provided in Table4. For girls, C and E effects were substantial, but the small additive genetic effects were not significantly different from zero. For boys, A, C, and E effects were all

Table 3 Pairwise correlations for REL in the whole cohort, and among pairs living in the southern and northern parts of Finland

\begin{tabular}{lccc}
\hline Zygosity and gender & All pairs & South & North \\
\hline Female MZ & $0.71(460)$ & $0.63(265)$ & $0.79(195)$ \\
Male MZ & $0.67(319)$ & $0.72(182)$ & $0.60(137)$ \\
Female SS DZ & $0.67(386)$ & $0.62(212)$ & $0.70(174)$ \\
Male SS DZ & $0.54(399)$ & $0.51(232)$ & $0.58(167)$ \\
OS DZ & $0.51(829)$ & $0.46(455)$ & $0.55(374)$ \\
\hline
\end{tabular}

SS = same sex pairs, OS = opposite sex pairs

Table 4 Parameter estimates from best-fitting sex-limitation model for the full sample

\begin{tabular}{|c|c|c|c|c|}
\hline Full sample & $\begin{array}{l}\text { Additive } \\
\text { genetic }\end{array}$ & $\begin{array}{l}\text { components } \\
\text { confidence int } \\
\text { Common } \\
\text { environment }\end{array}$ & $\begin{array}{c}\text { Unique } \\
\text { environment }\end{array}$ & $\begin{array}{c}\text { Correlation between } \\
\text { common environmental effects } \\
\text { Rc }\end{array}$ \\
\hline Females & $\begin{array}{c}0.11 \\
(0.00-0.24)\end{array}$ & $\begin{array}{c}0.60 \\
(0.49-0.69)\end{array}$ & $\begin{array}{c}0.29 \\
(0.26-0.34)\end{array}$ & \\
\hline Males & $\begin{array}{c}0.22 \\
(0.06-0.38)\end{array}$ & $\begin{array}{c}0.45 \\
(0.31-0.57)\end{array}$ & $\begin{array}{c}0.34 \\
(0.29-0.39)\end{array}$ & $\begin{array}{c}0.84 \\
(0.73-0.99)\end{array}$ \\
\hline
\end{tabular}

Table 5 Parameter estimates from best-fitting sex-limitation model by region

\begin{tabular}{|c|c|c|c|c|c|}
\hline & & $\begin{array}{l}\text { Additive } \\
\text { genetic }\end{array}$ & $\begin{array}{l}\text { components } \\
\text { confidence int } \\
\text { Common } \\
\text { environment }\end{array}$ & $\begin{array}{c}\text { Unique } \\
\text { environment }\end{array}$ & $\begin{array}{c}\text { Correlation between } \\
\text { common environmental effects } \\
\text { Rc }\end{array}$ \\
\hline \multirow[t]{2}{*}{ Southern region } & Females & $\begin{array}{c}0.05 \\
(0.00-0.25)\end{array}$ & $\begin{array}{c}0.58 \\
(0.41-0.67)\end{array}$ & $\begin{array}{c}0.37 \\
(0.31-0.43)\end{array}$ & \\
\hline & Males & $\begin{array}{c}0.34 \\
(0.14-0.53)\end{array}$ & $\begin{array}{c}0.35 \\
(0.18-0.52)\end{array}$ & $\begin{array}{c}0.31 \\
(0.25-0.38)\end{array}$ & $\begin{array}{c}0.88 \\
(0.67-1.00)\end{array}$ \\
\hline \multirow[t]{2}{*}{ Northern region } & Females & $\begin{array}{c}0.19 \\
(0.04-0.35)\end{array}$ & $\begin{array}{c}0.59 \\
(0.44-0.72)\end{array}$ & $\begin{array}{c}0.22 \\
(0.18-0.27)\end{array}$ & \\
\hline & Males & $\begin{array}{c}0.07 \\
(0.00-0.33)\end{array}$ & $\begin{array}{c}0.55 \\
(0.34-0.66)\end{array}$ & $\begin{array}{c}0.38 \\
(0.30-0.47)\end{array}$ & $\begin{array}{c}0.85 \\
(0.72-0.99)\end{array}$ \\
\hline
\end{tabular}

significant contributors to variation in REL, but the shared environmental effects were not as prominent as those for girls. A comparison model constraining the $A, C$, and $E$ effects for males and females to be equal could be rejected by $\chi^{2}$ difference test $\left(\chi^{2}=6.69, \mathrm{df}=2, \mathrm{P}<0.05\right)$. This is a $2 \mathrm{df}$ test because, with \% variance parameters, once two are constrained to be equal, the third must al so be equal. Although the correlation between the shared environmental effects for girls and boys was significantly less than 1.0, the estimated correlation was quite high (0.84), and the confidence interval for the correlation ranged up to 0.99 . Thus, the model does indicate the presence of sex-specific shared environmental effects on REL, but these effects appear to be quite small. Given the modest level of sex-specific variation in REL, a model positing sex-specific genetic variation in place of sex-specific shared environments would have fitted the data almost as well. Given the non-significant genetic effects for girls, and the substantial shared environmental effects for both groups, we focus on the shared environmental correlation here.

Parameter estimates and confidence intervals for the model distinguishing twins living in the northern and southern regions are presented in Table 5. This model also provided an excellent fit to the data $\left(\chi^{2}=8.70, \mathrm{df}=16, \mathrm{P}=0.925\right)$. Confidence intervals are broader in this analysis, reflecting the fact that there are fewer twin pairs in each sex by region grouping. Power to make comparisons across sex within region, and across regions within sex is similarly reduced. Like the full sample analysis, the regional analyses suggested the presence of sexspecific shared environmental effects, although 
those effects reached significance only in the northern region. For twins living in the north, the only significant sex difference in parameter estimates was for unshared environmental effects $\left(\chi^{2}=10.85\right.$, $\mathrm{df}=1, \mathrm{P}<0.01)$, which explained a higher percentage of the variance in REL for boys. In the south, the only significant sex difference was for additive genetic effects $\left(\chi^{2}=4.00, \mathrm{df}=1, \mathrm{P}<0.05\right)$. For boys, genetic effects accounted for $34 \%$ of the total variation, and $49 \%$ of the familial variation (34/69). In contrast, genetic effects in girls (which were nonsignificant) accounted for only $5 \%$ of the total variation and $8 \%$ of familial variation (5/63). Girls in the south had significantly higher unshared environmental estimates than girls in the north $\left(\chi^{2}=13.03\right.$, $\mathrm{df}=1, \mathrm{P}<0.01$ ), whilst unshared environmental estimates for boys were quite similar in the two regions. Neither additive genetic nor shared environmental estimates differed significantly within sex but across the two regions, reflecting the low power of the classical twin model to differentiate additive genetic and shared environmental effects, particularly when using only half of the sample for each comparison.

In order to use all the data, we asked a slightly different question. Are the A, C, or E estimates for a given sex by region group significantly different from the pooled estimates from the remaining three groups? This was accomplished by setting a nonlinear constraint in $\mathrm{Mx}$. For additive genetic effects only the boys in the southern region, who had higher genetic effects, were found to differ significantly from the pooled estimates $\left(\chi^{2}=3.91, \quad \mathrm{df}=1\right.$, $\mathrm{P}<0.05)$. In a corresponding manner, the boys in the southern region also had significantly lower shared environmental effects than the other groups $\left(\chi^{2}=5.03, \mathrm{df}=1, \mathrm{P}<0.05\right)$. Shared environmental estimates in the other groups were very similar. Girls in the northern region had significantly lower unshared environmental estimates $\left(\chi^{2}=13.634\right.$, $\mathrm{df}=1, \mathrm{P}<0.01)$. Estimates in the other three groups were very similar.

\section{Discussion}

Among Finnish adolescents during the 1990s, the heritability of religiosity, as assessed by the REL scale, is very modest, and shared environmental effects account for most of the variation in religiosity. The contribution of familial factors to individual differences in religiosity appears to differ somewhat by sex and residential area.

Religiosity of Finns, assessed with the REL scale, may differ from that of the USA. In a structured telephone interview of a population sample in the midwest United States (age range 19-99, $n=1408$ ), raw score REL means were $>7$ among women and $>6$ among men. The means increased with age, especially among women and were negatively correlated with education, especially among men. ${ }^{23}$ REL means among college men (mean age 20, $\mathrm{n}=800$ ) were comparable. ${ }^{24}$ In the present study, mean scores are considerably lower than in these American samples, indicating a higher prevalence of secular beliefs. The anal ysis of item specific endorsement frequencies indicated that across nearly all items, girls endorsed items more frequently than boys, and those living in northern Finland more than those in southern Finland. Items measuring churchgoing and Bible reading (see Table 1) had the lowest percentages and belief in God was the highest, which nicely demonstrates the typical Finnish (and Scandinavian) way of religiousness.

Earlier twin, family, and adoption studies of religiosity suggest significant, and often substantial shared environmental effects. A large study of college-age twins, ${ }^{25}$ using a factor-derived MMPI scale of Religious Orthodoxy, found only slightly higher MZ than DZ correlations, with $c^{2}$ estimates of 0.48 (in women) to 0.65 (in men), and small estimates of genetic variance. Adding adoption data, mostly on adolescents and young adults, from the Texas Adoption Project, to these college-age twin data, an estimated $c^{2}$ of $50 \%$ was obtained. ${ }^{26}$ Results from the present study, with the 12-item REL scale, are quite consistent with these American reports.

Other studies have used somewhat different scal es and measures of religiosity. A recent study of $>1900$ adult female twins ${ }^{27}$ found significant shared environmental effects for three religiosity scales of personal devotion (24\%), personal conservatism $(45 \%)$ and institutional conservatism (51\%) among 1902. Genetic effects were significant only for personal devotion (29\%) and institutional conservatism $(12 \%)$. In the same sample, religiosity was protective of substance use and abuse, but not associated with psychiatric symptoms or disorders. A study of extended twin kinships ${ }^{28}$ showed that shared environmental effects (accounting for over 20\% of variance) were important al so for church attendance frequency.

In contrast to these studies of twins reared together, data of the REL scale in a small sample of twins reared apart ${ }^{29}$ reported intraclass correlations for $M Z$ twins reared apart ( $n=50 \mathrm{MZA}$ pairs) of 0.55 but, for $30 \mathrm{DZA}$ twin pairs, a correlation not significantly different from zero. Also assessed were four other measures of religious interests, attitudes and values for which somewhat higher DZ correlations were found. For all five measures the $M Z$ correlations exceeded the DZ correlations, and model fitting indicated heritabilities of $40-50 \%$ for these scales. In an updated analysis with more 
pairs, ${ }^{30}$ the correlation of REL for $65 \mathrm{MZA}$ pairs was 0.63 and for 54DZA pairs -0.12. Model-fitting indicated that this scale was the only one of the 13 Wiggins Content Scales to fit poorly a genetic model specifying additive genetic variance and unique environmental factors. To the degree that the MZA results are inconsistent with other research literature, such inconsistency may reflect small samples.

Earlier Finnish studies reported that religiosity varies by sex and residential area. ${ }^{3-5}$ These studies show adolescents in the south to be more secularized than the youth from Ostrobothnia (north-western coastal region). There are also clear differences in religious behavior (attending religious meetings, churchgoing and believing as the church teaches) between the more urban south and the other more rural areas. ${ }^{31}$ How should these regional differences be reflected in changes in the genetic and environmental determinants of individual differences in religiosity? Cross-cultural studies have suggested that the effect of family religiosity on children's religious views is stronger in countries where average religiosity is lower, ${ }^{32}$ which would suggest that there should stronger common (family) environmental effects on religiosity in the more secular southern parts of the country. In contrast, a study of adolescent drinking behavior ${ }^{33}$ reported that girls from rural areas showed greater vulnerability to family influences than girls from other areas, implying that non-familial sources of variance may be more important in the urban areas. Our results were not entirely consistent with either of these simple, if contradictory, predictions. For girls, our results showed no difference in family environmental influence in the north and south, but non-familial sources of variance were significantly greater in the urban south, consistent with the latter view. It is possible that this reflects a greater diversity of non-familial environmental influences to which adol escents may be exposed in urban areas. For boys, however, we found no increase in non-familial environmental effects in the urban areas. Instead, boys living in the urban south appeared to have decreased family environmental effects and increased genetic effects compared with the other groups of subjects. This result can be reconciled with the general hypothesis of greater diversity of non-familial environments in urban areas only by positing that genetic influences are being expressed in the choice of religion-rel evant environments to which the boys are being exposed, so that greater variation in non-familial environments is reflected in a higher estimate of genetic influence. Unfortunately, the current data on the religiosity phenotype alone provide rather limited information on the urban-rural differences and are not adequate to support a specific view of the processes underlying those differences. In addition to measures of religiosity, future studies should strive to measure hypothesized religion-relevant environments, their distribution in different regions, and their covariance among family members. Such studies would offer a more complete description of the processes underlying regional differences in the determinants of individual differences in religiosity.

\section{Acknowledgements}

FinnTwin 16 is supported by the National Institute of Alcohol Abuse and Alcoholism (AA 08315) and from the Academy of Finland (grant No. 42044); preparation of the paper was supported by a NIAAA grant to the Indiana Alcohol Research Center (AA 07611) and by the Finnish Foundation for Alcohol Studies. The authors are grateful to Olli Lounela and Kauko Heikkilä for technical assistance and database management.

\section{References}

1 Karvonen S. The regional context of health behaviour among Finnish adol escents. STAKES (National research and development centre for welfare and health). Research reports 76 : Jyväskylä, 1997, 192 pp.

2 Rose RJ, Kaprio J, Winter T, Koskenvuo M, Viken RJ. Familial and socio-regional environmental effects on abstinence from alcohol at age 16. JStud Alcohol 1999; 13 Suppl: 63-74.

3 Helve $\mathrm{H}$. The role of religion in postmodern society. A Iongitudinal study of the values of contemporary young Finns. Temenos 1994; 30: 81-93.

4 Helve H. Religion, world views and gender ideology. Temenos 1995; 31: 77-92

5 Helve H. What happened to young 'humanists', 'individualists' and 'traditionalists'? A comparative study of changing value-worlds of young people in the framework of postmodernity. Council of Europe: European youth centres youth research and documentation. Research papers 1998. (http:/ /www.coe.fr/youth/research/hel ena.htm.)

6 Rohrbaugh J, Jessor R. Religiosity in youth: a personal control against deviant behavior. J Personality 1975; 43: 136-155.

7 Francis LJja, Mullen K. Religiosity and attitudes towards drug use among 13-15year olds in England. Addiction 1993; 88: 665-672.

8 Wallace $\mathrm{M}$, Williams DR. Religion and adolescent healthcompromising behavior. In: Health Risks and Developmental Transitions During Adolescence. Cambridge University Press: Cambridge, pp 444-468. Schulenberg J, Maggs $\mathrm{L}$, Hurrel mann K. (eds) 1997.

9 Burkett SR. Perceived parents' religiosity, friends' drinking, and hellfire: a panel study of adolescent drinking. Rev Relig Res 1993; 35: 134-141.

10 Burkett SR, Warren BO. Religiosity, peer associations, and adolescent marijuana use: a panel study of underlying causal structures. Criminology 1987; 25: 109-131.

11 Uskonto ja terveys (religiosity and health). Terveyskasvatuksen neuvottelukunta. Lääkintöhallituksen julkai suja. Sarja Tilastot ja selvitykset. 1990, 3: $82 \mathrm{pp}$. 
12 Heino $\mathrm{H}$, Salonen K, Rusama J, Ahonen R. Evangelisklutherska kyrkan i Finland åren 1992-1995 (The Finnish Lutheran Church). Kyrkans forskningscentral: Jyväskylä, 1997, 372 pp.

13 Heino H, Sal onen K, Rusama J. Response to recession. No. 47. Research Institute of the Evangelical Lutheran Church of Finland: Saarijärvi, 1997, 83 pp.

14 Uskonnolliset yhteisöt (Religious communities). In: Suomen kartasto nro 124 (Atlas of Finland). 3. Yhteiskunta. Kulttuuri. Elinolot. Karttakeskus: Helsinki, 1993,pp 17-27.

15 Larsen S. The origin of alcohol-related social norms in the Saami minority. Addiction 1993; 88: 501-508.

16 Kaprio J, Rimpelä A, Winter T, Viken RJ, Rimpelä M, Rose J. Common genetic influences on BMI and age at menarche. Hum Biol 1995; 67: 739-753.

17 Wiggins $\mathcal{J}$. Substantive dimensions of self report in the MMPI item pool. Psychol Monogr 1966; 80: 22 (whole no. 630).

18 Kunnat 1998. Alueluokitukset. Käsikirjoja no. 28. Helsinki: Tilastokeskus 1998. (Handbook of regional classification, Statistics Finland, Helsinki)

19 Statistical Yearbook of Finland 1997. Statistics Finland: Hämeenlinna, 1997

20 Williams CJ, Christian JC, Norton JA. TWINAN90: A FORTRAN program for conducting ANOVA-based and likelihood-based analyses of twin data. Comput Meth Programs Biomed 1992; 38: 167-176.

21 Neale MC, Boker SM, Xie G, Maes HH. Mx: Statistical Modeling. 5th edn. Department of Psychiatry, MCV: Richmond, VA.

22 Neale MC, Cardon LR. Methodology for Genetic Studies of Twins and Families. Kluwer Academic: Dordrecht, 1992.

23 Colligan RC, Offord KP. Contemporary norms for the Wiggins content scales: a 45-year update. J Clin Psychol 1988; 4: 23-32.
24 Knowles EE, Schroeder DA. Personality characteristics of sons of alcohol abusers. J Stud Alcohol 1990; 51: 142-147.

25 Rose RJ. Genetic and environmental variance in content dimensions of the MMPI. J Pers Soc Psychol 1988; 55: 302-311.

26 Beer MM, Arnold RD, Loehlin JC. Genetic and environmental influences on MMPI factor scales: joint model fitting to twin and adoption data. J Pers Soc Psychol 1998; 74: 818-827.

27 Kendler KS, Gardner CO, Prescott CA. Religion, psychopathology, and substance use and abuse: a multimeasure, geneticepidemiologic study. Am J Psychiatry 1997; 154: 322-329.

28 Truett KR, Eaves LJ, Walters EE, Heath AC, Hewitt K, Meyer M, Silberg J, Neale MC, Martin NG, Kendler KS. A model system for analysis of family resemblance in extended kinships of twins. Behav Genet 1994; 24: 35-49.

29 Waller NG, Kojetin BA, Bouchard TJjr, Lykken DT, Tellegren A. Genetic and environmental influences on religious interests, attitudes and values: a study of twins reared apart and together. Psychol Science 1990; 1: 138-142.

30 DiLalla DL, Carey G, Gottesman II, Bouchard TJjr. Heritability of MMPI personality indicators of psychopathology in twins reared apart. J Abnorm Psychol 1996; 105: 491-499.

31 Sorri H. Itsemurha ja uskonnollisuus (Suicide and religiosity). Sarja A no. 61. Kirkon tutkimuskeskus: Pieksämäki, 1993, 266 pp.

32 Kelly J, De Graaf ND. National Context, parental socialization, and religious belief: results from 15 nations. Am Sociol Rev 1997; 62: 639-659.

33 Kelleher KJ, Rickert VI, Hardin BH, Pope SK, Farmer FI. Rurality and gender. Effects on early adolescent alcohol use. Am JDis Child 1992; 146: 317-322. 